\title{
SPORT CLASSES AS EFFECTIVE MEANS FOR PSYCHOPHYSICAL HEALTH IMPROVEMENT OF REPRESENTATIVES OF THE SECURITY AND DEFENSE SECTOR
}

DOI: $10.36740 /$ WLek202105118

\author{
Ivan M. Okhrimenko' , Maksym 0. Hrebeniuk ${ }^{2}$, Mykola 0. Borovyk ${ }^{3}$, Mykola M. Krasnopolskyii, \\ Mykhailo 0. Rodionov ${ }^{4}$, Yurii I. Kuzenko ${ }^{4}$, Yevhenii 0. Korak ${ }^{4}$ \\ 'NATIONAL ACADEMY OF INTERNAL AFFAIRS, KYIV, UKRAINE \\ 2INSTITUTE OF DEPARTMENT OF STATE GUARD OF UKRAINE, TARAS SHEVCHENKO NATIONAL UNIVERSITY OF KYIV, KYIV, UKRAINE \\ ${ }^{3}$ KHARKIV NATIONAL UNIVERSITY OF INTERNAL AFFAIRS, KHARKIV, UKRAINE \\ ${ }^{4}$ ODESA MILITARY ACADEMY, ODESA, UKRAINE
}

\begin{abstract}
The aim: Is to investigate the influence of sport classes on the psychophysical health of Ukrainian Armed Forces' servicemen.

Materials and methods: The level of servicemen's health was estimated according to the professor Apanasenko's methodology based on the anthropometric and functional indicators. In the research there were 120 cadets aged 18 to 22 from 0desa Military Academy. Methods of research: analysis of scientific works, medical and biological methods, experiment, statistics analysis.

Results: It was found out at the end of the experiment that the health level of the cadets who attended Crossfit classes is significantly higher than that of the cadets who studied according to the standard physical training program. The most profound effect was revealed on the functionality of the cardiovascular, respiratory and muscular systems, and the stabilization of body weight of cadets of experimental groups.

Conclusions: The results of the research show sufficiently high effectiveness of the Crossfit classes for the purpose of improving cadets' psychophysical health during studying. High psychophysical health level formed during the Crossfit training increases longevity and resistance of the body to unfavourable factors of professional activity, reduces the risk of professional diseases and improves the efficiency of the official duties performance.
\end{abstract}

KEY WORDS: Crossfit, physical training, health, cadets

Wiad Lek. 2021;74(5):1142-1146

\section{INTRODUCTION}

Combat activities in the eastern part of Ukraine have been carried out for its independence for more than seven years. The military leaders are concerned with the issues of maintaining the servicemen's psychophysical health at the level that would ensure their assigned combat missions are fulfilled, and reduction of soldiers' injuries [1,2]. The modern battle takes place in extreme conditions and is characterized by the influence on Ukrainian Armed Forces's servicemen of such unfavorable factors as: permanent staying in a state of nervous and physical stress, fatigue, low motor activity during longterm stay in confined space (at checkpoints, in blindfolds); carrying on considerable weights (weapons, equipment, ammunition); the necessity to act at night, in any weather and on any terrain. Negative influence of combat activity factors causes such negative changes in the body of servicemen as: metabolic disorders, increase in body weight, increase injuries, various diseases and the level of health decrease, deterioration of psychological state indicators $[3,4,5]$.

In the works of many scientists $[6,7,8,9]$ it has been determined that physical training has significant opportuni- ties in improving the efficiency of servicemen's professional activity, in improving their health and ability to work. Literature analysis $[10,11]$ showed that one of the modern kinds of sport is Crossfit, which has several advantages over other sports and exercises: sports equipment compactness; possibility of training both within limited space and in the open area; the opportunity to conduct both self-training and exercises simultaneously with a large group of people; a wide range of simple and available exercises eliminates the possibility of adaptation to the same type of load; possibility to conduct exercises simultaneously with servicemen of different levels of physical preparedness, high efficiency in the development of physical qualities (strength and endurance) and moral-volitional qualities, strengthening the muscles of the whole body.

\section{THE AIM}

The aim is to investigate the influence of sport classes (Crossfit classes) on the psychophysical health of Ukrainian Armed Forces' servicemen. 


\section{MATERIALS AND METHODS}

To determine the influence of Crossfit exercises on the dynamics of psychophysical health indicators of cadets, a control group $(\mathrm{CG}, \mathrm{n}=57)$ and two experimental groups (EG1, n=30, EG2, n=33) were formed. The groups were formed from cadets aged 18-22 who entered the Odesa Military Academy in 2015 with the similar indicators of physical preparedness and health $(\mathrm{p}>0.05)$. In EG1 there were cadets who studied in the Crossfit section of academy; in EG2 there were the cadets, who studied in the Crossfit section of the faculty; in CG there were cadets, who studied according to the traditional physical training program. The amount of hours on physical training in all groups was the same (12 hours a week).

The research of the physical health level (PHL) was carried out according to professor H. L. Apanasenko's methodology [12] based on the indicators of anthropometry, and the state of the cardiovascular system. The methodology consisted in determining the amount of points for each of the 5 indicators: body mass index, vital capacity index, power index, Robinson index, heart rate recovery time to initial level after 20 squats per 30 seconds.

Methods of research: theoretical analysis and generalization of scientific and methodological works, medical and biological methods, methods of mathematical statistics.

Researches related to the involvement of cadets were carried out in compliance with Order of the Minister of Defense of Ukraine «On Approval of the Regulation on the Organization of Scientific, Scientific and Technical Activities in the Armed Forces of Ukraine» dated 27.07.16, No. 385. Informed agreement was received from all people involved in this research.

\section{RESULTS}

Based on the conclusions of many scientists' works and taking into account the results of our previous researches, we substantiated the authors' program of improving the cadets' health by means of Crossfit. It combines the components of a holistic pedagogical process - from goals to the final result and focused on the personality of a future officer who has a high level of physical training and health, has physical education and fitness competencies for implementation of the means of physical training and sports in the sphere of professional activity and is capable of performing the tasks of military and professional (combat) activity effectively. The main objectives of the authors' program include: increasing the level of physical training of graduates with an emphasis on the development of strength qualities and endurance which are the most effective in ensuring their future military and professional (combat) activities; improvement of the health state of future officers; improvement of the methodological training level of future officers in the field of physical education and special physical training and sport; mastering the knowledge, skills and abilities concerning the use of physical training means and sport for the prevention of injuries both in the process of future professional activities and at physical training classes and while doing sport; formation of the necessity and positive attitude to systematic physical exercise and sport of the future defenders of Ukraine.

The implementation of the authors' program was carried out in 2015-2019 in 3 stages: stage 1- training of cadets of the $1^{\text {st }}$ year of study, stage 2 - the period of training of cadets of the $2^{\text {nd }}$ year; stage 3 - training of cadets of $3^{\text {rd }}-4^{\text {th }}$ years of study. The content of each stage varied depending on the main pedagogical objectives of the stage and was determined by differentiated correlations of means, methods, load measures, types of training. Dosing and load regulation at the stages of the authors' program was carried out by the change in the volumes and intensity of means, individual classes, magnitude and direction of loads, taking into account the individual capabilities of each cadet, level of their training; it was determined by the peculiarities of the application and the order of combining components as: the type, duration and nature of individual exercises, number of lifts, rounds and classes, pace of movements, time of exercises, weight of encumbrance, duration and nature of the pause between individual repetitions, the rounds, exercises. The main objective during the load planning was taking into account the regularities of the adaptation of the cadets' body to physical activity in order to ensure that the effect of each subsequent class was «stratified» on the «traces» of the previous class improving and deepening it. In the course of development of the authors' program, the objective was to minimize the cadets missing the educational process in the MEHE. Therefore, the classes were based on a substantiated authors' program within the limits of the existing forms of physical education: physical training classes and sports-mass work that ensured the full course of the educational process.

In order to check the effectiveness of the experimental health promotion program by means of Crossfit, we applied the method of express assessment of the level of somatic health developed by H. L. Apanasenko based on the calculated body mass index, vital capacity index, power index, Robinson index and heart rate recovery time.

Thus, the analysis of the body mass index (BMI) showed that during the $1^{\text {st }}-2^{\text {rd }}$ years of study the BMI did not differ significantly $(\mathrm{p}>0.05)$. On the $3^{\text {th }}$ year of study better indicators were revealed in EG1 compared with CG for $1 \mathrm{~kg} / \mathrm{m}^{2}$ $(\mathrm{p}<0.05)$, and on the $4^{\text {th }}$ year of study in EG1 $\left(23.2 \mathrm{~kg} / \mathrm{m}^{2}\right)$ and in EG2 $\left(23.6 \mathrm{~kg} / \mathrm{m}^{2}\right)$ the BMI was revealed to be significantly better than in CG $\left(24.5 \mathrm{~kg} / \mathrm{m}^{2}\right)$ by $1.3 \mathrm{~kg} / \mathrm{m}^{2}$ $(\mathrm{p}<0.01)$ and $0.9 \mathrm{~kg} / \mathrm{m}^{2}(\mathrm{p}<0.05)$ respectively (Table I). It is important to note that during the experiment, the BMI in cadets from CG significantly deteriorated by $1.4 \mathrm{~kg} / \mathrm{m}^{2}$ $(\mathrm{p}<0.001)$, while it did not change significantly in EG1 and EG2 (p>0.05). (Table I)

The research of the vital capacity index (VCI) showed that while in the $2^{\text {nd }}-4^{\text {th }}$ year of study the VCI for cadets of EG1 and EG2 was revealed to be significantly better compared with CG $(\mathrm{p}<0.05-0.001)$. The greatest difference between the respiratory system indicators in the cadets of the research groups was revealed at the end of the experiment - the VCI in EG1 (63.3 ml/kg) and EG2 $(61.2 \mathrm{ml} / \mathrm{kg})$ 
Table I. Dynamics of cadets health indicators during the pedagogical experiment ( $n=120$, Mean $\pm S D)$

\begin{tabular}{|c|c|c|c|c|c|c|}
\hline \multirow{2}{*}{ Research stages } & \multirow{2}{*}{$\begin{array}{c}\text { EG1 } \\
(n=30)\end{array}$} & \multirow{2}{*}{$\begin{array}{c}\text { EG2 } \\
(n=33)\end{array}$} & \multirow{2}{*}{$\begin{array}{c}\text { CG } \\
(n=57)\end{array}$} & \multicolumn{3}{|c|}{ Significant level } \\
\hline & & & & p1-p2 & p2-p3 & p1-p3 \\
\hline \multicolumn{7}{|c|}{ Body mass index, $\mathrm{kg} / \mathrm{m} 2$} \\
\hline 1 st year of study & $23.4 \pm 0.43$ & $23.3 \pm 0.37$ & $23.1 \pm 0.18$ & $>0.05$ & $>0.05$ & $>0.05$ \\
\hline 2nd year of study & $23.5 \pm 0.40$ & $23.7 \pm 0.40$ & $24.2 \pm 0.22$ & $>0.05$ & $>0.05$ & $>0.05$ \\
\hline 3rd year of study & $23.3 \pm 0.41$ & $23.6 \pm 0.38$ & $24.3 \pm 0.23$ & $>0.05$ & $>0.05$ & $<0.05$ \\
\hline 4th year of study & $23.2 \pm 0.40$ & $23.6 \pm 0.38$ & $24.5 \pm 0.24$ & $>0.05$ & $<0.05$ & $<0.01$ \\
\hline \multicolumn{7}{|c|}{ Vital capacity index, ml/kg } \\
\hline 1st year of study & $57.4 \pm 0.91$ & $57.4 \pm 0.85$ & $58.0 \pm 0.61$ & $>0.05$ & $>0.05$ & $>0.05$ \\
\hline 2nd year of study & $61.0 \pm 1.09$ & $59.8 \pm 1.02$ & $56.5 \pm 0.71$ & $>0.05$ & $<0.05$ & $<0.01$ \\
\hline 3rd year of study & $62.3 \pm 1.20$ & $60.6 \pm 1.08$ & $57.1 \pm 0.77$ & $>0.05$ & $<0.05$ & $<0.01$ \\
\hline 4th year of study & $63.3 \pm 1.28$ & $61.2 \pm 1.24$ & $56.8 \pm 0.82$ & $>0.05$ & $<0.01$ & $<0.001$ \\
\hline \multicolumn{7}{|c|}{ Power index, $\%$} \\
\hline 1st year of study & $54.8 \pm 1.60$ & $55.1 \pm 1.43$ & $54.8 \pm 0.97$ & $>0.05$ & $>0.05$ & $>0.05$ \\
\hline 2nd year of study & $65.6 \pm 1.75$ & $63.5 \pm 1.54$ & $56.9 \pm 1.05$ & $>0.05$ & $<0.01$ & $<0.001$ \\
\hline 3rd year of study & $70.9 \pm 1.79$ & $66.7 \pm 1.58$ & $58.1 \pm 1.12$ & $>0.05$ & $<0.001$ & $<0.001$ \\
\hline 4th year of study & $74.6 \pm 1.84$ & $68.6 \pm 1.62$ & $59.2 \pm 1.14$ & $<0.05$ & $<0.001$ & $<0.001$ \\
\hline \multicolumn{7}{|c|}{ Robinson index, c.u. } \\
\hline 1st year of study & $87.9 \pm 1.24$ & $87.8 \pm 1.17$ & $86.9 \pm 0.79$ & $>0.05$ & $>0.05$ & $>0.05$ \\
\hline 2nd year of study & $80.7 \pm 1.35$ & $83.5 \pm 1.24$ & $85.7 \pm 0.83$ & $>0.05$ & $>0.05$ & $<0.01$ \\
\hline 3rd year of study & $78.6 \pm 1.38$ & $81.6 \pm 1.29$ & $84.8 \pm 0.85$ & $>0.05$ & $<0.05$ & $<0.001$ \\
\hline 4th year of study & $74.2 \pm 1.40$ & $79.6 \pm 1.31$ & $85.5 \pm 0.84$ & $<0.01$ & $<0.001$ & $<0.001$ \\
\hline \multicolumn{7}{|c|}{ Heart rate recovery time, sec } \\
\hline 1st year of study & $139.6 \pm 4.02$ & $136.8 \pm 3.37$ & $137.4 \pm 2.62$ & $>0.05$ & $>0.05$ & $>0.05$ \\
\hline 2nd year of study & $105.7 \pm 2.83$ & $116.2 \pm 2.51$ & $127.8 \pm 2.18$ & $<0.05$ & $<0.01$ & $<0.001$ \\
\hline 3rd year of study & $96.4 \pm 2.17$ & $109.7 \pm 2.26$ & $122.5 \pm 1.90$ & $<0.001$ & $<0.001$ & $<0.001$ \\
\hline 4th year of study & $87.3 \pm 1.96$ & $98.2 \pm 1.85$ & $118.3 \pm 1.77$ & $<0.001$ & $<0.001$ & $<0.001$ \\
\hline
\end{tabular}

Note: p1-p2 - significance of difference between the indicators of EG1 and EG2; p2-p3 - significance of difference between the indicators of EG2 and CG; p1-p3 - significance of difference between the indicators of EG1 and CG

on the $4^{\text {th }}$ year of study was significantly higher than in CG $(56.8 \mathrm{ml} / \mathrm{kg})$ by $6.5 \mathrm{ml} / \mathrm{kg}(\mathrm{p}<0.001)$ and $4.4 \mathrm{ml} / \mathrm{kg}$ $(\mathrm{p}<0.01)$ respectively (Table I). The analysis also showed that for the entire period of the experiment, the indicators of cadets from EG1 and EG2 did not have a significant difference $(p>0.05)$. The analysis confirmed the positive effect of Crossfit classes. The research of the power index (PI) showed the high efficiency of Crossfit exercises in order to improve the muscular system in cadets of experimental groups. Thus, the cadets of EG1 who were on the $2^{\text {nd }}$ year of study had significantly higher indicators than the cadets of the CG by $8.7 \%(p<0.01)$. Significantly higher indicators were found in both experimental groups who were on the $3^{\text {rd }}$ year of study compared with the CG $(p<0.001)$. The indicators of cadets in EG1 who were on the $4^{\text {th }}$ year of study turned to be significantly better than in CG by $15.4 \%(\mathrm{p}<0.001)$, and in EG2 by $6 \%(\mathrm{p}<0.05)$ (Table I). The indicators of the PI significantly improved during the experiment in all groups but in the CG the difference between the initial and final data is $4.4 \%(\mathrm{p}<0.01)$, in EG2 - $13.5 \%(\mathrm{p}<0.001)$, and in EG1 - $19.8 \%(\mathrm{p}<0.001)$. Robinson index analysis showed the CG indicators were significantly lower on the $2^{\text {nd }}$ and $3^{\text {rd }}$ years of study than in experimental groups $(\mathrm{p}<0.05-0.001)$, and on the $4^{\text {th }}$ year of study the Robinson index was found to be the best in EG1 among other groups, it is 74.2 c.u. and it is significantly better than in CG ( 85.5 c.u.) by 11.3 c.u. $(\mathrm{p}<0.001)$ and EG2 (79.6 c.u.) in 5.9 c.u. $(p<0.01)$ (Table I). Analysis of the RI dynamics during the pedagogical experiment showed that in EG1 and EG2 the indicators were significantly improved ( $p<0.001$ ) by 13.7 c.u. and 8.2 c.u., but in CG they have not significantly changed $(p>0.05)$. The research of the HRR time to initial level after a standard load indicated that on the $2^{\text {nd }}$ year of study, there was a significant difference between the indicators of EG1 and CG $(p<0.001)$, and on the $3^{\text {rd }}$ and $4^{\text {th }}$ years of study the indicators of cadets of experimental groups were significantly better than in the CG by $19.8-31 \mathrm{sec}(\mathrm{p}<0.01 ; \mathrm{p}<0.001)$ (Table I). In addition on the $3^{\text {rd }}-4^{\text {th }}$ years of study, a significant difference $(\mathrm{p}<0.05-$ 0.001 ) was found between the indicators of EG1 and EG2, 
Table II. Dynamics of the physical health level of cadets during the experiment

\begin{tabular}{ccccccc}
\hline \multirow{2}{*}{ Research stages } & EG1 & EG2 & CG & \multicolumn{3}{c}{ Significant level } \\
\cline { 5 - 8 } & $(\mathbf{n = 3 0 )}$ & $(\mathbf{n = 3 3 )}$ & $\mathbf{( n = 5 7 )}$ & $\mathbf{p 1 - p 2}$ & $\mathbf{p 2 - p 3}$ & $\mathbf{p 1 - p 3}$ \\
\hline $1^{\text {st }}$ year of study & $2.92 \pm 0.39$ & $2.97 \pm 0.33$ & $3.08 \pm 0.26$ & $>0.05$ & $>0.05$ & $>0.05$ \\
\hline $2^{\text {nd }}$ year of study & $8.91 \pm 0.44$ & $7.74 \pm 0.38$ & $5.47 \pm 0.31$ & $>0.05$ & $<0.01$ & $<0.001$ \\
\hline $3^{\text {rd }}$ year of study & $10.44 \pm 0.47$ & $8.90 \pm 0.41$ & $7.62 \pm 0.36$ & $<0.05$ & $<0.01$ & $<0.001$ \\
\hline $4^{\text {th }}$ year of study & $12.61 \pm 0.51$ & $9.35 \pm 0.44$ & $7.59 \pm 0.35$ & $<0.01$ & $<0.01$ & $<0.001$ \\
\hline
\end{tabular}

$(n=120$, Mean \pm SD), points

it testifies about the effectiveness of Crossfit to improve the recovery processes in the cadets' body.

The research of the physical health level by H. L. Apanasenko's methodology showed that at the beginning of the experiment the cadets' PHL in all groups was in the range of 2.92-3.08 points, it did not differ significantly in all groups $(p>0.05)$ and was estimated as «low» (Table II).

Starting from the $2^{\text {nd }}$ year of study the PHL in EG1 and EG2 was significantly higher than in CG $(\mathrm{p}<0.01-0.001)$. Average PHL was revealed in all groups on the $3^{\text {rd }}$ year of study, while the indicators in EG1 (10.44 points) were significantly better comparing with CG (7.62 points) by 2.82 points ( $\mathrm{p}$ $<0.001$ ), and with EG2 (8.90 points) by 1.54 points ( $<<0.05)$. At the end of the experiment, the PHL of cadets in EG1 was recorded as the best among the research groups; it is 12.61 points and is estimated as «above average». This indicator is significantly better than in CG (7.59 points) by 5.02 points $(\mathrm{p}<0.001)$ and in EG2 (9.35 points) by 3.26 points $(\mathrm{p}<0.01)$. On the $4^{\text {th }}$ year of study in the CG and in EG2, the PHL is estimated as «average». During the experiment, PHL in all groups significantly $(\mathrm{p}<0.001)$ improved: in $C G-$ by 4.51 points, in EG2 - by 6.38 points, and in EG1 - by 9.69 points. It is important to note that average indicator of PHL of cadets in EG1 on the $4^{\text {th }}$ year of study (12.61 points), despite other groups according to H. L. Apanasenko's methodology, is in the «safe zone», where the there is almost no risk of somatic diseases. It proves the effectiveness of Crossfit classes concerning the improvement of cadets' health.

\section{DISCUSSION}

The necessity of finding the effective means to improve and maintain the servicemen's health at the level that would ensure accomplishment of their combat missions is quite relevant. The research has been made concerning the influence of Crossfit classes on the level of health of cadets who were engaged in Crossfit classes while studying.

The analysis of works of a number of scientists $[13,14]$ shows a high popularity of military and applied kinds of sport among the cadets, with an emphasis on the development of strength and endurance. Crossfit takes the leading place among those kinds of sport, and it has the positive influence of Crossfit exercises on the body $[10,11]$. Thus, in the works of scientists $[2,4,13]$ it is proved that power exercises contribute to the improvement of the health level, aesthetic self-improvement due to the proportionality and symmetry of the muscles and the all balanced development of all muscle groups, body correction, including elimination of disadvantages in it, recovery after injuries, increase of ability to work; the formation of a harmonious figure. The researches of scientists [11] have proved that regular Crossfit classes contribute to maintaining high ability to work, effective power development, general and power endurance, static endurance of the body muscles, coordination abilities while having a positive effect on the cardiorespiratory system and emotional state of those who do this sport. As a result of systematic Crossfit exercises, the volume of cardiac muscle gradually increases, the network of vessels that feed it increases; changes occur in blood composition (a number of red blood cells and hemoglobin increase); the girth of the chest increases, vital lung capacity increases; the activity of the central nervous system and mental working capacity improve; the intensity and concentration of attention get better. Our research confirms the conclusions of a number of scientists $[10,11,15,16,17,18,19,20]$ concerning the positive influence of Crossfit classes on physical health indicators of cadets. The biggest effect was revealed on the functional possibilities of the cardiovascular system, respiratory system, muscular system and stabilization of body weight indicators.

\section{CONCLUSION}

1. The level of physical health of cadets of EG1 and EG2 at the end of the experiment was significantly better $(p<0.05-0.001)$ than in the CG according to the indicators: the body mass index - by $1.3 \mathrm{~kg} / \mathrm{m}^{2}$ and $0.9 \mathrm{~kg} /$ $\mathrm{m}^{2}$, the vital capacity index - by $6.5 \mathrm{ml} / \mathrm{kg}$ and $4.4 \mathrm{ml} /$ $\mathrm{kg}$, the power index - by $15.4 \%$ and $9.4 \%$, the Robinson index - by $11.3 \%$ c.u. and 5.9 c.u., the heart rate recovery time - by $31 \mathrm{sec}$ and $20.1 \mathrm{sec}$, the physical health level according to the H. L. Apanasenko's methodology - by 5.02 points and 1.76 points. The biggest effect of Crossfit classes was revealed on the functional possibilities of the cardiovascular system, respiratory system, muscular system and stabilization of body weight of cadets.

2. The results of the researches testify to the high efficiency of Crossfit classes in order to improve the cadets' psychophysical health during the educational process and maintain it in the process of service on officer posts.

\section{REFERENCES}

1. Rolyuk A., Romanchuk S., Romanchuk V. et al. Research on the organism response of reconnaissance officers on the specific load of military exercises. J Phys Educ Sport. 2016; 16(1): 132-5. doi:10.7752/ jpes.2016.01022. 
2. Prontenko K., Griban G., Prontenko V. et al. Kettlebell lifting as a means of physical training cadets in higher military educational institution. J Phys Educ Sport. 2017; 17 (4): 2685-9. doi:10.7752/jpes.2017.04310.

3. Burley S.D., Drain J.R., Sampson J.A., Groeller H. Positive, limited and negative responders: the variability in physical fitness adaptation to basic military training. J Sci Med Sport. 2018; 21 (11): 1168-72. doi:10.1016/j.jsams.2018.06.018.

4. Prontenko K., Griban G., Prontenko V. et al. Health improvement of cadets from higher military educational institutions during kettlebell lifting activities. J Phys Educ Sport. 2018; 18(1): 298-303. doi:10.7752/ jpes.2018.01040.

5. Aandstad A., Hageberg R., Saether 0., Nilsen R. Change in anthropometrics and aerobic fitness in Air Force cadets during 3 years of academy studies. Aviat Space Environ Med. 2012; 83 (1): 35-41. doi: 10.3357/ ASEM.3069.2012.

6. Oliver J.M., Stone J.D., Holt C. et al. The effect of physical readiness training on reserve officers' training corps freshmen cadets. Mil Med. 2017; 182 (11): 1981-6. doi: 10.7205/milmed-d-17-00079.

7. Henning P.C., Park B-S., Kim J.S. Physiological decrements during sustained military operational stress. Mil Med. 2011; 176 (9): 991-7. doi: 10.7205/milmed-d-11-00053.

8. Prontenko K., Griban G., Aloshyna A. et al. Analysis of cadets' endurance development at higher military educational institutions during the kettlebell lifting training. Sport Mont. 2019; 17(2): 3-8. doi 10.26773/ smj.190601.

9. Mozolev 0., Halus 0., Bloshchynskyi I. et al. Human resources management of educational development in sphere of physical culture and sports in Ukraine: comparative analysis (1992-2016). Journal of Physical Education and Sport. 2019; 19(1): 185-92. doi:10.7752/ jpes.2019.s1028.

10. Glassman G. Understanding CrossFit. The CrossFit Journal. 2007; 56:5-6.

11. Osipov A., Kudryavtsev M., Gatilov K. et al. The use of functional training - Crossfit methods to improve the level of special training of athletes who specialize in combat sambo. J Phys Educ Sport. 2018; 17 (3): 201318. doi:10.7752/jpes.2017.03201.

12. Apanasenko G. L. Knygha o zdorovj'e [Health Book]. Kyiv: Medknygha; 2007; 132. (in Russian).

13. Zocoler C.A., Madureira D., Santana J.0. et al. Short term power exercises increase physical fitness in middle aged adults. J Phys Educ Sport. 2018; 182: 1223-1230. doi:10.7752/jpes.2018.s2182.

14. Prontenko K., Bloshchynskyi I., Griban, G. et al. Formation of readiness of future physical culture teachers for professional activity. Universal Journal of Educational Research. 2019; 7(9): 1860-8. doi: 10.13189/ ujer.2019.070903.

15. Griban G., Lyakhova N., Tymoshenko 0. et al. Current state of students' health and its improvement in the process of physical education. Wiad. Lek. 2020; 73(7): 1438-47. doi: 10.36740/WLek202007124.
16. Prontenko K., Griban G., Dovgan N. et al. Students' health and its interrelation with physical fitness level. Sport Mont. 2019; 17(3): 41-6. doi 10.26773/smj.191018.

17. Griban G., Yavorska T., Tkachenko P. et al. Motor activity as the basis of a healthy lifestyle of student youth. Wiad. Lek. 2020; 73(6): 1199-1206. doi: 10.36740/WLek202006123.

18. Prontenko K., Griban G., Aloshyna A. et al. The physical development and functional state as the important components of the students' health. Wiad. Lek. 2019; 72(12a): 2348-53. doi: 10.36740/WLek201912115.

19. Griban G., Kobernyk 0., Terentieva N. et al. Formation of health and fitness competencies of students in the process of physical education. Sport Mont. 2020; 18 (3): 73-78. doi: 10.26773/smj.201008.

20. Prontenko K., Griban G., Bloshchynskyi I. et al. Improvement of students' morpho-functional development and health in the process of sport-oriented physical education. Wiad Lek. 2020; 73(1): 161-168. doi: 10.36740/WLek202001131.

\section{ORCHID and contributionship:}

Ivan M. Okhrimenko: 0000-0002-8813-5107 ${ }^{A, E}$

Maksym O. Hrebeniuk: 0000-0003-1139-4095,D

Mykola O. Borovyk: 0000-0003-0943-6735,D

Mykola M. Krasnopolskyi: 0000-0002-1225-6463 ${ }^{F}$

Mykhailo O. Rodionov: 0000-0002-3278-3359

Yurii I. Kuzenko: 0000-0001-6725-058X ${ }^{E}$

Yevhenii O. Korak: 0000-0002-0301-1106 ${ }^{B}$

\section{Conflict of interest:}

The Authors declare no conflict of interest.

\section{CORRESPONDING AUTHOR} Ivan M. Okhrimenko

National Academy of Internal Affairs

1 Solomianska Square, 02000 Kyiv, Ukraine

tel: +380679903905

e-mail: ivango-07@ukr.net

Received: 04.01.2021

Accepted: 31.03 .2021

A - Work concept and design, B - Data collection and analysis, C - Responsibility for statistical analysis, D-Writing the article, $\mathbf{E}$-Critical review, $\mathbf{F}$ - Final approval of the article 